\title{
Origin of Replication
}

National Cancer Institute

\section{Source}

National Cancer Institute. Origin of Replication. NCI Thesaurus. Code C13335.

A DNA sequence necessary and sufficient for initiation of DNA replication. 